\title{
An automated resource for enhanced differential analysis
}

\author{
Kai Wang ${ }^{1}$, Charles A Phillips ${ }^{1}$, Arnold M Saxton², Michael A Langston ${ }^{1 *}$ \\ From 14th Annual UT-KBRIN Bioinformatics Summit 2015 \\ Buchanan, TN, USA. 20-22 March 2015
}

\section{Background}

Differential Shannon entropy (DSE) and differential coefficient of variation (DCV) have proven to be effective complements to differential expression (DE) in the analysis of gene co-expression data[1]. Because DSE and DCV measure difference in variability, rather than mere difference in magnitude, they can often identify significant changes in gene activity not reflected in mere mean expression level.

\section{Materials and methods}

Thus, we have devised a general purpose, easy-to-use $\mathrm{R}$ package to calculate DSE and DCV. Dubbed Entropy Explorer, this package operates on two numeric matrices with identically labeled rows, such as case/control transcriptomic data. All functionality has been wrapped into one routine. With a single procedure call a user may select a metric, whether to display that metric, its raw and adjusted p-value, or both, whether to sort by metric or raw or adjusted p-value, and how many of the most highly ranked results to display.

\section{Authors' details}

${ }^{1}$ Department of Electrical Engineering and Computer Science, University of Tennessee, Knoxville, TN 37996-2250, USA. ²Department of Animal Science, University of Tennessee Institute of Agriculture, Knoxville, TN 37996-4574, USA.

\section{Published: 23 October 2015}

\section{Reference}

1. Wang K, Phillips CA, Rogers GL, Barrenas F, Benson M, Langston MA: Differential Shannon Entropy and Differential Coefficient of Variation: Alternatives and Augmentations to Differential Expression in the Search for Disease-Related Genes. International Journal of Computational Biology and Drug Design 2014, 183-194.

\footnotetext{
* Correspondence: langston@tennessee.edu

${ }^{1}$ Department of Electrical Engineering and Computer Science, University of Tennessee, Knoxville, TN 37996-2250, USA

Full list of author information is available at the end of the article
}

doi:10.1186/1471-2105-16-S15-P20

Cite this article as: Wang et al:: An automated resource for enhanced differential analysis. BMC Bioinformatics 2015 16(Suppl 15):P20.
Submit your next manuscript to BioMed Central and take full advantage of:

- Convenient online submission

- Thorough peer review

- No space constraints or color figure charges

- Immediate publication on acceptance

- Inclusion in PubMed, CAS, Scopus and Google Scholar

- Research which is freely available for redistribution
() Biomed Central
C Biomed Central

(c) 2015 Wang et al. This is an Open Access article distributed under the terms of the Creative Commons Attribution License (http:// creativecommons.org/licenses/by/4.0), which permits unrestricted use, distribution, and reproduction in any medium, provided the original work is properly cited. The Creative Commons Public Domain Dedication waiver (http://creativecommons.org/publicdomain/ 